\title{
Bulgarian Mining Industry between Tradition and Innovation
}

\author{
Aneta Deneva ${ }^{1}$, and Jānis Grasis ${ }^{2}$ \\ ${ }^{1}$ D. A. Tsenov Academy of Economics, Svishtov, Bulgaria \\ ${ }^{2}$ BA School of Business and Finance, Riga Stradins university, Riga, Latvia
}

\begin{abstract}
Extractive activities are traditional for the Bulgarian economy and are part of the economic activity of the population since the establishment of the Bulgarian state. As an autonomous sector of the economy, they are approved after 1878. The initial extractive activities are carried out with the direct participation of foreign capital, mainly French, German and Belgian. The extraction of raw materials has always been among the priority economic areas. Not surprisingly with the first economic laws adopted by the Bulgarian Government is supported its development. A typical example in this respect is the law on the promotion of the local industry since 1909. Among the promotion activities are mining, metal industry, as well as the quarry and that for the processing of soil materials. The mining industry is an indispensable part of the structure of the Bulgarian economy, regardless of its transformations.
\end{abstract}

\section{Introduction}

Mining activities are the basis of the extractive sector, which include: extraction of underground natural resources, primary processing and transportation to the processing plants. Unfortunately, the territory of our country is not distinguished by a large number and rich in precious substances natural raw materials. The restriction of the raw material base is one of the most important limiting factors in the Bulgarian economy. The main types of extracted raw materials are lignite coal, polymetallic ores, lead zinc and copper ores, kaolin, gypsum, limestone, quartz sand, marble, bentonite, etc. As per the Bulgarian chamber of Mining and geology the total number of deposits is 595. They are allocated as follows [1]:

- Metallic Minerals - 206;

- Non-metallic minerals - 115;

- Oil and natural gas -3 ;

- Rock-lining materials - 51;

- Building materials - 151;

- Solid Fuels - 69

According to the Bulgarian legislation, the demand for and extraction of the natural resources, which are exclusive state property, is carried out on the basis of a search permit obtained and a concession for their extraction. As per the National Registration register [2], 
the Bulgarian state has granted 377 concessions for natural underground treasures. In the directions they are allocated as follows:

- Mining of metallic minerals - 19 concessions;

- Extraction of non-metallic minerals - 67 concessions;

- Oil and natural gas - 15 concessions;

- Solid fuels - 20 concessions;

- Building materials - 216 concessions;

- Rock-lining materials - 38 concessions;

- Gold mining - 1 concession;

- Mining waste -1 concession.

The average duration of such concessions varies from 22 to 26 years. The biggest number of the concessioners in the mining of construction materials -143 , and the smallest - in mining waste -1 .

In the extractive sector of the country in 2018 [3] operate 338 enterprises, which employ a total of 21554 persons. By number of employees, enterprises are divided into 5 main groups:

- Over 250 people - 12;

- From 50 to 249 people - 31;

- From 20 to 49 people - 34;

- From 10 to 19 people -43 ;

- From 0 to 9 people -218 enterprises.

Among the top 10 companies in the sector are the following companies - "Mini Maritsa Iztok" EAD, "Ellatzite-med" AD, Dundee Precious Metals Inc. Chelopech, "AssarelMedet" AD, Kaolin AD, "Ognyanovo-K" AD, " VARBA - BATANTSI" AD, etc.

\section{Materials and methods}

The Bulgarian mining industry has go through major structural changes over the last 30 years. At the end of the 80 years of the last century it developed in several main directions coal case, ferrous metallurgy, non-ferrous metallurgy, construction materials industry, oil extraction and from. Due to the specific sector structure of the economy during this period, these sectors are not among the frontrunners. Although traditional, their percentage is too low. The reasons for this are several:

- The coal deposits are small in number, and the coal produced in them is low in valuable substances, which necessitates their enrichment before the incorporation in production. Similarly, are the condition in the nonferrous metallurgy. It is again necessary to enrich the extracted raw materials.

- The steelmakers, although well developed during this period, rely primarily on cheap imported raw materials, not on their own.

- The situation of petroleum products is similar. Built large capacity in the oil refinery mainly used inexpensive raw materials imported from the former Soviet Union.

- Only the construction materials industry, as well as porcelain faience rely only on their own raw materials. This is a reason for this period to have a higher percentage in the sector structure of the Bulgarian economy.

With the start of the restructuring and privatisation processes from the beginning of the 90 years, the economic sectors have been undergoing significant changes. Some of them, including the mining, are experiencing major difficulties. With the collapse of the former Council for Mutual Economic Assistance, the possibility of using cheap imported raw materials is abolished. This cause a collapse in many businesses relying primarily on these resource sources. Another part is losing the main markets for the realization of the manufactured products. At the fastest pace, the companies in extracting industries, 
metallurgy, cement, glass and porcelain-faience industries are reduced. All of them are invariably connected to the extractive sector and therefore the negative processes in them are reflected directly and on it. The impact of the crisis in the big Bulgarian processing enterprises such as steel Stomana-Pernik, Kremikovtzi AD-Sofia, Plama Oil AD Pleven, which are the largest companies in the field of metallurgy and oil processing, should not be overlooked. In parallel, privatisation processes started, which, from the very beginning, strongly affected extractive activities. The structural reforms carried out and the Currency board introduced at the end of 90 years deepen the restructuring processes in the mining industry.

The transformations in the mining industry continued at a significant rate until 2007. They can be traced using a variety of indicators. The most obvious are the amendments to the "number of enterprises" and "employed persons" indicators (Fig. 1).
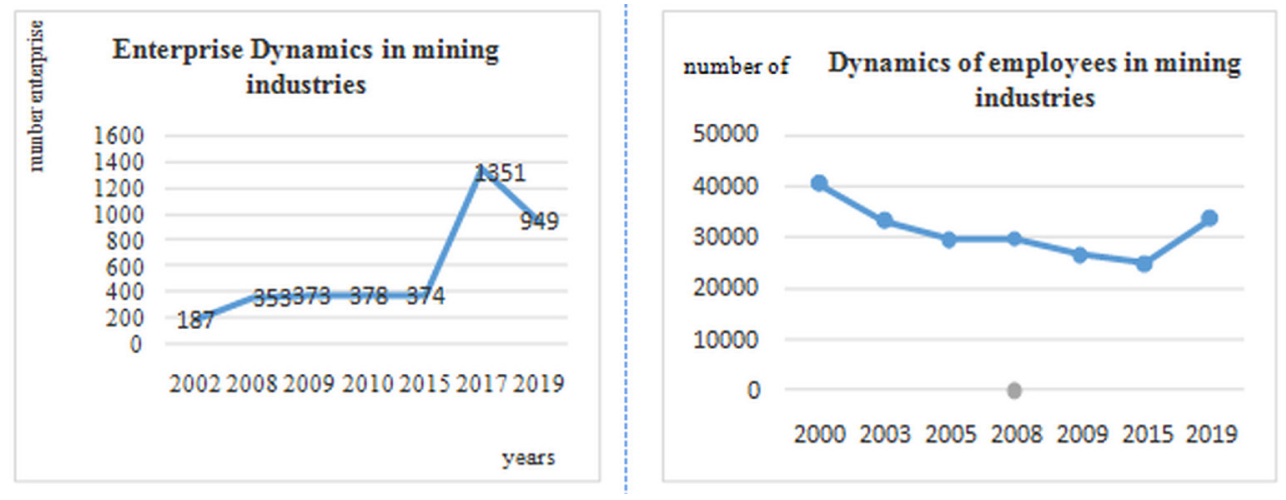

Fig. 1. Dynamics of the indicators "number of enterprises" and "number of employees" in the mining industry of the Republic of Bulgaria for the period $2000-2015$.

The main structural changes mining industry underwent in the 90 years of the last century, when significantly reduced not only the number of enterprises but also the employees. Right then in the Bulgarian economy operates the smallest number of enterprises in the mining sector -187 . The abbreviation of the number of employees in them from 64995 people in 1996 to 33394 people in 2003 was also significant. Further impact also launched privatization. The changes made cause a stabilization and growth of the economic performance of the research sector. As a result, not only the indices of the production produced in the sector grow, but also its percentage in the overall structure of the Bulgarian economy. After 2003, the mining industry became one of the primary sectors of economy and the country specializes in the production of ferrous and non-ferrous metals $-18.3 \%$ of the total industrial production [4].

In 2006 the mining industry take leading positions in the extraction of a number of raw materials - 10-th place in the world in the extraction of bismuth, 31-st place in the extraction of zinc, 20-th place in the extraction of copper, 19-th place in the production of coal [5]. „Ellatzite mine“ becomes the largest in the Balkans and one of the largest in eastern Europe. The extraction of gold is significantly increased -4 tons per year, which is carried out mainly by the concessionaire Dundee precious metals. The concessions granted during the period are a prerequisite for an increase in the number of enterprises and for a certain stabilization of the number of employees observed in 2008.

Unfortunately, the crisis of 2008-2010 has had a negative impact on the industry, which, however, has been overcome as a result of the measures taken and, in particular, the new regulatory framework. In 2015, the National Strategy for the Development of Mining Industry was developed and adopted [6], which outlines the main goals and activities for 
individual sub-sectors of the mining sector. Based on the SWOT analysis, the strengths and weaknesses of the sector are identified and the necessary actions are planned. As a result, since 2015, the number of enterprises has increased sharply and the negative trend in terms of employees in this industry has been overcome. This gives reason to speak for the revival of the mining industry [1, 7-10].

Today, the mining industry forms $5 \%$ of the country's GDP, despite the fact that it employs only $4 \%$ of the employees in the Bulgarian industry [11]. A distinctive mark of the industry is its relatively high productivity. After power engineering and information technology, the mining industry is in third place of Gross value added per worker. In the last four years it accounts for $4 \%$ of the production of industrial enterprises in the country $[3]$.

\section{Strengths}

$\checkmark$ Bulgaria is one of the richest biodiversity countries in Europe with low levels of air, water and soil pollution. The territory is distinguished by the presence of extensive ecologically clean territories and a large number of potential sites for study.

$\checkmark$ Well-developed environmental monitoring system. Regulatory framework established and programs adopted for the implementation of environmental policies. )

$\checkmark$ Availability of a specific geo-fund for underground resources - good geological study and information security.

$\checkmark$ Great potential for finding new mineral deposits $(\mathrm{Cu}, \mathrm{Au}$, etc.) and for developing nontraditional raw materials - various types of minerals from the group of industrial minerals. Clean areas and a large number of potential sites for exploration.

$\checkmark$ The extractive industry is crucial for the development of the industries along the technological chains - metallurgy, construction, chemical industry, mechanical engineering, electrical engineering, electronics, etc.

$\checkmark$ The gross value added of an employee in the Extractive Industries Sector is growing and is significantly higher than the total for the country and the industry.

$\checkmark$ It is directly related to the political and financial stability of Bulgaria.

\section{Weaknesses}

$\checkmark$ The underground riches are non-renewable resources.

$\checkmark$ Significant territories fall within Natura 2000 areas, which creates limitations and requires additional procedures

$\checkmark$ Competition with other land users such as construction, agriculture, tourism, nature conservation, etc.

$\checkmark$ Low-quality coal reserves.

$\checkmark$ Unresolved waste related problems.

$\checkmark$ Create risks (deterioration of working environment parameters, negative social effects, air pollution, noise, soil and water contamination and impact on groundwater level, disruption of relief and landscape and visual impact on the surrounding landscape-to their recultivation), which can be managed by achieving quality of the environment and working conditions.

$\checkmark$ Risks of accidents and incidents peculiar to heavy industry.

$\checkmark$ Long duration of the investment process - from the survey to the realization of mining projects.

$\checkmark \quad$ Unfair competition. Presence of a grey sector and illegal extraction of construction, stone cladding materials and industrial minerals.

$\checkmark \quad$ Insufficient use of the available incentive funds provided by different European programmes.

Lack of sufficient administrative capacity to enforce the requirements of the new legal acts.

Fig. 2. SWOT analysis of the mining industry in Bulgaria (first part). 


\section{Opportunities}

To match national environmental prionities with the priorities of the intemational communities the UN, the EU and others for which environmental protection is a priority.

$\checkmark \quad$ The conscious need at EU level to assess and exploit the mineral-raw potential of the Member States.

$\checkmark$ Constantly growing global and national consumption of raw materials and energy.

$\checkmark$ High demand for metals, industrial minerals, oil and gas in global markets.

$\checkmark$ Development of non-traditional raw materials.

$\checkmark$ Use of green technologies.

$\checkmark$ Rapid development of production technologies, mining and processing equipment.

$\checkmark$ Development of equipment and technologies, creating opportunities for ecological and healthy (safe) production, as well as for exploration and extraction of increasingly accessible underground treasures, at increasing depths and with ever lower contents of useful components.

$\checkmark$ Implementation of leading global and European technologies in the extraction and processing of underground resources for increasing the extraction of useful components and reduction of losses in extraction and processing.

$\checkmark$ Restructuring of extractive industries.

$\checkmark$ Public attitudes to support efforts to protect the environment.

$\checkmark$ To ensure a balanced economical and environmentally responsible approach to exploration, extraction and processing for the sustainable development of the mineral-raw industry

$\checkmark$ Development products with higher value added on the technological circuits after the extraction and processing of underground treasures.

Effective collection and recycling of waste throughout the technological chain of processing of me tal, petroleum and other products in all downstream industries after extraction.

\section{Threats}

The global climate change and the fall of the country into the drought zone.

$\checkmark$ The high costs of implementing European environmental legislation.

$\checkmark$ Ongoing process of deterioration of the forestry fund.

$\checkmark$ Old technologies in industry and power engineering and risk of unrealization of expected economic growth on their basis.

$\checkmark$ Unclear regulation on the monitoring and maintenance and financing of the extractive industries ' liquidated objects.

$\checkmark$ Ineffective dialogue on discussion with non-govemmental environmental organisations.

$\checkmark$ Ineffective communications with potential investors who have expressed interest in search and research.

$\checkmark$ High market risk, especially for exchange products due to cyclical periods at lower and higher prices with large amplitudes.

$\checkmark$ Risk of lack of market balance (demand supply) in building materials due to unbalanced processes for searching and researching these materials.

$\checkmark$ The collapsed consumption of local stone materials and the need to take protective measures against imports from non-EU countries.

$\checkmark$ A significant risk of unfair competition in the form of illegal extractive activities.

$\checkmark$ Lack of policy for demand planning, exploration and extraction of the underground resources, overcoming conflict with protected areas of Natura 2000, with energy networks, project routes from the system of the whole national infrastructure (gas, road, railway, etc.), as well as with plans for development of territories adopted by the local authorities.

$\checkmark$ Ddifficult access to land.

$\checkmark$ Significant investment in environmental brotection and reclamation.

Fig. 2. SWOT analysis of the mining industry in Bulgaria (last part). 


\section{Results and discussion}

The following strengths and weaknesses, as well as the existing advantages and potential threats to the mining sector can be identified based on the developed SWOT analyzes on the state and development of the Bulgarian mining sector [12-17] (Fig 2,3).

The mining industry is a traditional sector of the Bulgarian economy. It is also one of the most complex - technically challenging, highly monopolized, many different business and geopolitical interests involved, and only the military sector surpasses it for security concerns. These are also part of the reasons why the sector is highly regulated and generally quite consolidated.

With the modern scale of extraction of raw materials, the problem of the interaction between it and the environment acquires an extremely acute nature [18-19]. The contradiction between the constantly growing needs of raw materials and fuels and the scarcity of the stocks of the traditional natural resources of our planet deepens. The extraction of raw materials and fuels, as well as the construction of large hydro energy sites for energy purposes change the face of whole areas.

However, what is causing the greatest concern is environmental pollution. It is undisputed that the mining industry is one of the major polluters. A particularly significant share in this respect is the processes related to the extraction of fuels, aggregates, ores, petroleum products, natural gas, etc. Lowering the negative impact of the mining sector is related to the introduction of innovative technologies in the field of demand, extraction and exploitation of natural resources. A significant share in this direction is also the revegetation of the land and the preservation of biodiversity [16].

\section{Conclusions}

The mining sector is always subject to numerous discussions and myths. Not once in our business history has questioned the need for its development [19]. Many more often emphasize the negative sides related to its functioning - environmental pollution, depletion of non-renewable resources, losses of agricultural areas, high costs for reclamation of the Land Fund, etc. The many theories and doctrines that have arisen in recent decades for the "bio economy", "circular economy", "green", "blue", etc. economy also contribute to a significant degree of such negativity towards the sector concerned.

In practice, however, human civilization cannot exist without the extraction of minerals. No country can afford the luxury of not developing the mining sector. It is of strategic importance for the economy and is at the heart of the development of all other industrial sectors and its essential role in terms of economic sustainability and energy independence of individual countries should not be forgotten.

\section{References}

1. Renascence of the Mining Industry. URL: https://www.bmgk.bg/wpcontent/uploads/2019/02/Renascence_MiningIndustry_2014.pdf.

2. National Concession Register. URL: https://nkr.government.bg/

3. National statistical institute. Statistical data. URL: https://www.nsi.bg/bg/content/7697/

4. A. Deneva, The asymmetric in the Bulgarian industry (Tsenov Academic Publishing, Svishtov, 2013)

5. National Minerals Information Center. URL: https://www.usgs.gov/centers/nmic/zincstatistics-and-information 
6. National strategy for development of the mining industry. URL: https://www.me. government.bg/files/useruploads/files/vop/minstrategy/minna_strategia2015.pdf

7. M. Petrova, M. Tepavicharova, L. Dikova, E3S Web Conf., 41, 04017 (2018)

8. R. Pukala, M. Petrova, E3S Web Conf., 105, 04034 (2019)

9. N. Kurmanov, M. Petrova, S. Suleimenova, E3S Web Conf., 105, 04045 (2019)

10. K. Mussapirov, J. Djalkibaev, G. Kurenkeyeva, A. Kadirbergenova, M. Petrova, L. Zhakypbek, Entrepreneurship and Sustainability Issues, 7:2, 1480-1495 (2019)

11. A. Zahariev, M. Zveryakov, S. Prodanov, G. Zaharieva, P. Angelov, S. Zarkova, M. Petrova, Entrepreneurship and Sustainability Issues, 7:3, 2382-2393 (2020)

12. I. Gryshova, M. Petrova, M. Tepavicharova, A. Diachenko, T. Gutsul, Entrepreneurship and Sustainability Issues, 7:1, 690-703 (2019)

13. A. Deneva, G. Sirashki, H. Sirashki, Tz. Spasovsky, Extraction of raw materials and greening of the mining industry (Tsenov Academic Publishing, Svishtov, 2012)

14. Assessment of the macroeconomic importance of the mineral resources industry in Bulgaria. URL: https://www.mediapool.bg/files/233/

15. L. Stemplewska Corruption in business - pros and cons (Tsenov Academic Publishing, Svishtov, 2018)

16. L. Levashova Problemy zarzadzania kapitałem ludzkim - wyzwania współczesności (Wydawnictwo L\&J Techtrading sp. z o.o., Warszawa, 2010)

17. O. Baklanova, M. Petrova, V. Koval, Economic Studies, 29:1, 68-91 (2020)

18. I. Kolechkina, I. Verchagina, E. Eltsova, M. Petrova, E3S Web Conf., 134, 02004 (2019)

19. M. Tepavicharova, L. Dikova, V. Zahars, E3S Web Conf., 105, 04029 (2019) 